\title{
Regulation of smooth muscle contractility by the epithelium in rat tracheas: role of prostaglandin $\mathrm{E}_{2}$ induced by the neurotransmitter acetylcholine
}

\author{
Lei Zhao ${ }^{1,2,3 \#}$, Yu-Ting Liang ${ }^{3 \#}$, Dong-Bo Tian ${ }^{1,2 \#}$, Rui-Gang Zhang ${ }^{3,4}$, Jiehong Huang ${ }^{3}$, Yun-Xin Zhu ${ }^{3}$, \\ Wen-Liang Zhou ${ }^{3}$, Yi-Lin Zhang ${ }^{3} \wedge$ \\ ${ }^{1}$ Department of Respiration, Qingyuan People’s Hospital, the Sixth Affiliated Hospital of Guangzhou Medical University, Guangzhou Medical \\ University, Guangzhou, China; ${ }^{2}$ School of Basic Medical Sciences, Guangzhou Medical University, Guangzhou, China; ${ }^{3}$ School of Life Sciences, Sun \\ Yat-sen University, Guangzhou, China; ${ }^{4}$ Department of Physiology, Basic Medical School, Guangdong Medical University, Zhanjiang, China \\ Contributions: (I) Conception and design: L Zhao, WL Zhou, YL Zhang; (II) Administrative support: YX Zhu, J Huang; (III) Provision of study \\ materials or patients: WL Zhou, YL Zhang; (IV) Collection and assembly of data: YT Liang, DB Tian, RG Zhang, YL Zhang; (V) Data analysis and \\ interpretation: L Zhao, YT Liang, DB Tian, YL Zhang; (VI) Manuscript writing: All authors; (VII) Final approval of manuscript: All authors. \\ \#These authors contributed equally to this work. \\ Correspondence to: Yi-Lin Zhang; Wen-Liang Zhou. School of Life Sciences, Sun Yat-sen University, No. 132, East Waihuan Road, Guangzhou \\ Higher Education Mega Center, Guangzhou 510006, China. Email: zhangylin9@mail.sysu.edu.cn; 1sszw1@mail.sysu.edu.cn.
}

Background: Previous studies have suggested the involvement of epithelium in modulating the contractility of neighboring smooth muscle cells. However, the mechanism underlying epithelium-derived relaxation in airways remains largely unclear. This study aimed to investigate the mechanism underlying epithelium-dependent smooth muscle relaxation mediated by neurotransmitters.

Methods: The contractile tension of Sprague-Dawley (SD) rat tracheal rings were measured using a mechanical recording system. Intracellular $\mathrm{Ca}^{2+}$ level was measured using a $\mathrm{Ca}^{2+}$ fluorescent probe Fluo-3 AM, and the fluorescence signal was recorded by a laser scanning confocal imaging system. The prostaglandin $\mathrm{E}_{2}\left(\mathrm{PGE}_{2}\right)$ content was measured using an enzyme-linked immunosorbent assay kit.

Results: We observed that the neurotransmitter acetylcholine (ACh) restrained the electric field stimulation (EFS)-induced contraction in the intact but not epithelium-denuded rat tracheal rings. After inhibiting the muscarinic ACh receptor ( $\mathrm{mAChR}$ ) or cyclooxygenase (COX), a critical enzyme in prostaglandin synthesis, the relaxant effect of $\mathrm{ACh}$ was attenuated. Exogenous $\mathrm{PGE}_{2}$ showed a similar inhibitory effect on the EFSevoked contraction of tracheal rings. Moreover, ACh triggered phospholipase $\mathrm{C}$ (PLC)-coupled $\mathrm{Ca}^{2+}$ release from intracellular $\mathrm{Ca}^{2+}$ stores and stimulated $\mathrm{COX}$-dependent $\mathrm{PGE}_{2}$ production in primary cultured rat tracheal epithelial cells.

Conclusions: Collectively, this study demonstrated that ACh induced rat tracheal smooth muscle relaxation by promoting $\mathrm{PGE}_{2}$ release from tracheal epithelium, which might provide valuable insights into the cross-talk among neurons, epithelial cells and neighboring smooth muscle cells in airways.

Keywords: Cyclooxygenase (COX); neurotransmitter; prostaglandin $\mathrm{E}_{2}\left(\mathrm{PGE}_{2}\right)$; smooth muscle relaxation; tracheal epithelium

Submitted Jul 24, 2020. Accepted for publication Nov 26, 2020.

doi: 10.21037/atm-20-5500

View this article at: http://dx.doi.org/10.21037/atm-20-5500

\footnotetext{
$\wedge$ ORCID: 0000-0001-5350-8279.
} 


\section{Introduction}

The contractility of smooth muscle cells is precisely regulated by the neighboring cells, including neurons and epithelial cells. After stimulation, the pro-contractile neurotransmitters are released from nerve terminals and evoke maximal contraction of the adjacent smooth muscles (1-4). On the other hand, epithelial cells actively modulate the local smooth muscle tone via the release of various relaxing factors, including prostaglandins, nitric oxide (NO), cytokines, and the recently identified bacterial permeability family member A1 (5-9). The balanced smooth muscle contractility resulting from the contribution of nerve and epithelium is important in promoting respiration, gastrointestinal motility, micturition, and parturition. Once smooth muscle contractility dysfunction occurs, it may lead to various clinical disorders such as asthma, dyspepsia, overactive bladder, and dysmenorrhea (10).

As a dominant neurotransmitter in airways, acetylcholine (ACh) is primarily released from parasympathetic nerves and regulates airway smooth muscle tone. After combining with the muscarinic ACh receptors (mAChR), ACh activates phospholipase $\mathrm{C}$ (PLC) pathways and induces elevation of intracellular $\mathrm{Ca}^{2+}$ concentration $\left\{\left[\mathrm{Ca}^{2+}\right]_{i}\right\}$ of airway smooth muscle cells, which leads to the contraction (11-13). Although ACh has long been considered a strong bronchoconstrictor, previous evidence has demonstrated that ACh also showed an epithelium-dependent relaxant effect on histamine-contracted human bronchial rings (14). However, the regulatory mechanism underlying epitheliumdependent relaxation remains largely unclear, and the candidate molecules for epithelium-derived relaxing factor (EpiDRF) in airways still need to be identified. Prostaglandins have long been known for their relaxant effect on the smooth muscles. In human airway epithelial cells, the generation of prostaglandins could be induced by ACh $(15,16)$, which indicated that neurotransmitters such as ACh might trigger prostaglandin production and induce smooth muscle relaxation. Rats have been widely used as a model for allergen-induced asthma. Therefore, this study aimed to investigate the involvement of epithelium-derived prostaglandins in the dual regulatory effect of ACh on smooth muscle contractility in rat airways and identify the underlying mechanism.

We present the following article in accordance with the ARRIVE reporting checklist (available at http://dx.doi. org/10.21037/atm-20-5500).

\section{Methods}

Animals

Male Sprague-Dawley (SD) rats (7-8 weeks with bodyweight between 180-200 g) were purchased from Guangdong Medical Laboratory Animal Centre and housed in a specific pathogen-free room with 12 to $12 \mathrm{~h}$ lightand-dark cycle. Food and water were provided ad libitum. Experiments were performed under a project license (No. 0013122401) granted by the institutional ethics board of Sun Yat-sen University, in compliance with Sun Yat-sen University institutional guidelines for the care and use of animals.

\section{Reagents}

Keratinocyte serum-free medium (K-SFM), Hank's balanced salt solution, trypsin, penicillin, and streptomycin were purchased from Gibco (Carlsbad, CA, USA). Fetal bovine serum was purchased from Hyclone Laboratories (Logan, UT, USA). ACh, L-NG-nitro-arginine (L-NNA), indomethacin, prostaglandin $\mathrm{E}_{2}\left(\mathrm{PGE}_{2}\right), \mathrm{U} 73122$, and thapsigargin $(\mathrm{Tg})$ were purchased from Sigma Aldrich (St. Louis, MO, USA). Fluo-3 AM was purchased from Molecular Probes (Eugene, OR, USA). Atropine sulfate was purchased from Hengiian Pharmacy (Jiangmen, China). $\mathrm{NaCl}, \mathrm{KCl}, \mathrm{CaCl}_{2}, \mathrm{MgCl}_{2}, \mathrm{NaHCO}_{3}, \mathrm{MgSO}_{4}, \mathrm{KH}_{2} \mathrm{PO}_{4}$, Glucose, and $\mathrm{Na}_{2} \mathrm{HPO}_{4}$ were purchased from Guangzhou Chemical Reagent Factory (Guangzhou, China). N-2hydroethypiperazine-N'-2-ethanessulfonic acid (HEPES) was purchased from Biocolor BioScience \& Technology (Shanghai, China).

\section{Measurement of contractile tension}

The contractile tension of rat tracheal rings was measured with a modified procedure, as previously described (17-19). Briefly, the SD rats were sacrificed by $\mathrm{CO}_{2}$ inhalation, followed by isolation of tracheas incubated in KrebsHenseleit (K-H) solution containing (in $\mathrm{mM}$ ) $\mathrm{NaCl}$ [117], $\mathrm{KCl}$ [4.7], $\mathrm{CaCl}_{2}$ [2.5], $\mathrm{MgSO}_{4}$ [1.2], $\mathrm{NaHCO}_{3}$ [24.8], $\mathrm{KH}_{2} \mathrm{PO}_{4}$ [1.2], D-glucose [11.1] bubbled with $95 \% \mathrm{O}_{2} / 5 \%$ $\mathrm{CO}_{2}$. Then the tracheal rings were cut into two portions 
with $6 \mathrm{~mm}$ length. To remove the epithelium, the tracheal rings were threaded onto silk surgical threads and rolled three revolutions on a dish filled with $\mathrm{K}-\mathrm{H}$ solution as previously described (20). The epithelium removal was confirmed by the contractile response induced by bradykinin $(1 \mu \mathrm{M})$ in rat tracheal rings (21). The contractile tension was recorded using a mechanical recording system (BL420E+, Chengdu Taimeng Technology, Chengdu, China). The tracheal rings were equilibrated for $45 \mathrm{~min}$ with $5 \mathrm{mN}$ pre-loaded tension. Then, electric field stimulation (EFS) was applied via two filamentary silver connected to a stimulator. The stimulation parameters were $5 \mathrm{~s}$ for the duration, $10 \mathrm{~Hz}$ for frequency, and $0.5 \mathrm{~ms}$ for square pulse duration. Before the experiments, EFS pulses ranging from 10 to $35 \mathrm{~V}$ were applied to ensure that the contractile force reached $10 \mathrm{mN}$. All the experiments have been conducted within $2 \mathrm{~h}$ to avoid time-dependent variation of EFSinduced contraction. The number of experimental and control groups were indicated in the figure legends.

\section{Primary culture of rat tracheal epithelial cells}

Rat tracheal epithelial cells were cultured with a modified procedure, as previously described (22). In brief, the tracheas were isolated and bathed in Hank's balanced salt solution. After removing the blood vessels and connective tissues, the tracheas were digested enzymatically in $0.25 \%$ (w/v) trypsin at $4{ }^{\circ} \mathrm{C}$ overnight. The tracheas were then digested at room temperature for another $30 \mathrm{~min}$ before the enzyme activity was terminated. The isolated cells were harvested by centrifugation at $200 \times \mathrm{g}$ for $5 \mathrm{~min}$. The tracheal epithelial cells were cultured in K-SFM supplemented with epidermal growth factor $(5 \mathrm{ng} / \mathrm{mL})$, bovine pituitary extract $(50 \mu \mathrm{g} / \mathrm{mL})$, penicillin $(100 \mathrm{U} / \mathrm{mL})$, and streptomycin $(100 \mu \mathrm{g} / \mathrm{mL})$ at $37{ }^{\circ} \mathrm{C}$ with $5 \% \mathrm{CO}_{2}$ in a humidified atmosphere. $\mathrm{P} 0$ cells without subculture were used in all the experiments.

\section{Measurement of $\left[\mathrm{Ca}^{2+}\right]_{i}$}

The intracellular $\mathrm{Ca}^{2+}$ level was measured with a modified procedure, as previously described (17). The primary cultured rat tracheal epithelial cells were grown on the glass coverslips for 3 days. Before the experiment, the cells were washed three times using the normal physiological saline solution (NPSS) containing (in $\mathrm{mM}$ ) $\mathrm{NaCl}$ [137], $\mathrm{KCl}$
[5], $\mathrm{CaCl}_{2}$ [2.5], $\mathrm{MgCl}_{2}$ [1], D-glucose [10], HEPES [10] and incubated with the $\mathrm{Ca}^{2+}$ indicator Fluo-3 AM $(5 \mu \mathrm{M})$ dissolved in NPSS at room temperature for $45 \mathrm{~min}$. After another three times wash step with NPSS, the coverslip was mounted onto a chamber perfused with $2 \mathrm{~mL}$ NPSS. The $530 \mathrm{~nm}$ Fluo-3 fluorescence signal excited at $488 \mathrm{~nm}$ was recorded at $3 \mathrm{~s}$ intervals using a laser scanning confocal imaging system (TCS SP2; Leica Microsystems, Wetzlar, Germany). The cells were equilibrated for at least $60 \mathrm{~s}$ before the administration of ACh. Inhibitors were added $15 \mathrm{~min}$ before the $\left[\mathrm{Ca}^{2+}\right]_{\mathrm{i}}$ measurement. The change of the fluorescence intensity after treatment was normalized to the initial intensity. The number of experimental and control groups were indicated in the figure legends.

\section{Measurement of $\mathrm{PGE}_{2}$}

Primary cultured rat tracheal epithelial cells were washed and incubated in K-SFM at $37^{\circ} \mathrm{C}$. ACh $(200 \mu \mathrm{M})$ was added to the wells and incubated for $15 \mathrm{~min}$. The supernatant was then collected and centrifuged $\left(4^{\circ} \mathrm{C}, 2,000 \times \mathrm{g}, 4 \mathrm{~min}\right)$ to remove cellular debris. Indomethacin $(10 \mu \mathrm{M})$ was added $15 \mathrm{~min}$ before the administration of $\mathrm{ACh}$. $\mathrm{PGE}_{2}$ in the supernatant was measured using an enzyme-linked immunosorbent assay kit (R\&D Systems, Mineapolis, MN, USA) following the manufacturer's instructions. The protein content of the cells was measured by the bicinchoninic acid protein assay kit (CWBIO, Beijing, China). The number of experimental and control groups were indicated in the figure legends.

\section{Statistical analysis}

Data were presented as mean \pm SEM. The student's $t$-test was used to compare the means between two groups. For three groups, data were analyzed with one-way analysis-ofvariance, followed by Bonferroni for multiple comparisons. $\mathrm{P}<0.05$ was considered as significant difference.

\section{Results}

\section{ACb inbibited EFS-evoked contraction of rat tracheal rings in an epithelium-dependent manner}

EFS was applied to elicit a stable contraction of rat tracheal rings. The EFS-evoked contraction could be repeated nine times during $2 \mathrm{~h}$ of the experiment. After applying 
A

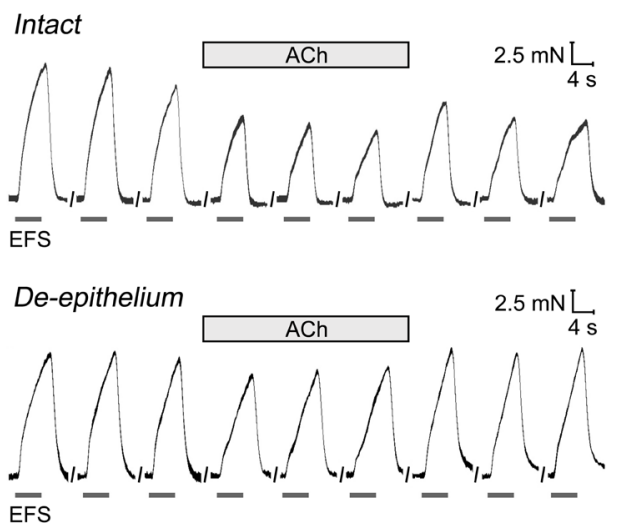

B

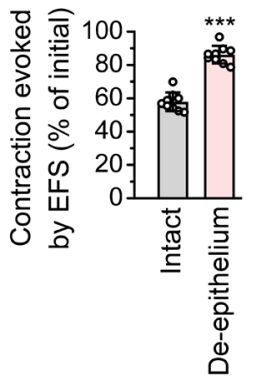

Figure 1 Relaxant effect of acetylcholine (ACh) on electric field stimulation (EFS)-contracted rat tracheal rings. (A) Representative traces showing the relaxant effect of ACh $(20 \mathrm{nM})$ on the contraction evoked by EFS in intact and epithelium-denuded rat tracheal rings with (B) the corresponding statistical analysis. Data were presented as a percentage of the initial contraction evoked by EFS. Each column and error bar indicated the mean \pm SEM. $n=9$; ${ }^{* * *}, \mathrm{P}<0.001$ compared with the intact trachea group. The experiment was repeated at least three times.

ACh $(20 \mathrm{nM})$, a small transient contraction was observed (Figure S1). EFS was then applied when the basal tone returned to normal. Notably, the EFS-evoked contraction was markedly inhibited in the presence of $\mathrm{ACh}$, and the amplitude of EFS-induced contraction recovered when the ACh was removed (Figure 1A).

To investigate whether epithelium was implicated in the ACh-induced inhibitory effect, epithelium-denuded tracheal rings were used in the subsequent experiments. As shown in Figure 1, the inhibition of ACh on EFS-induced contraction was significantly attenuated after epithelium removal, revealing that the relaxant effect of ACh on EFSevoked contraction was epithelium-dependent.

\section{Involvement of $m A C b R$ in $A C b$-induced relaxant effect on EFS-contracted rat tracheal rings}

Previous studies have demonstrated that ACh induced a potent dilation via interaction with $\mathrm{mAChR}$ in brain cortical arterioles (23). However, the possible involvement of $\mathrm{mAChR}$ in the relaxant effect of ACh in airways remains unclear. We then questioned whether mAChR mediated the inhibitory effect of ACh on EFS-evoked contraction. After pretreatment with atropine $(2 \mu M)$, a non-selective antagonist of mAChR, ACh failed to attenuate the contraction response evoked by EFS in rat tracheal rings (Figure 2). Therefore, the relaxant effect of ACh on EFSevoked contraction may be mediated by mAChR located on the tracheal epithelium.

\section{The ACb-induced relaxant effect on EFS-contracted rat tracheal rings was not mediated by NO}

As a well-known endothelium-derived relaxant factor, NO plays crucial roles in regulating the contractility of smooth muscle from the vessel and other tubular structures, including airways $(8,24,25)$. We next sought to explore whether NO participated in the ACh-induced relaxant effect on EFS-contracted rat tracheal rings. Surprisingly, after the addition of L-NNA $(300 \mu \mathrm{M})$, a NO synthase inhibitor, the relaxant effect of ACh on EFS-evoked contraction was not significantly altered (Figure 3), which excluded the involvement of $\mathrm{NO}$ in $\mathrm{ACh}$-induced relaxant effect on rat tracheas.

\section{Involvement of cyclooxygenase (COX)-PGE ${ }_{2}$ signaling in ACb-induced relaxant effect on EFS-contracted rat tracheal rings}

Because the relaxing factor $\mathrm{PGE}_{2}$ could be released in human airway epithelial cells after stimulation with ACh (15), we then testified the putative involvement of COX-PGE ${ }_{2}$ signaling in the inhibitory effect of ACh. As illustrated in Figure 4, indomethacin $(10 \mu \mathrm{M})$, a nonselective COX inhibitor, markedly suppressed ACh-induced relaxation response. Additionally, exogenous $\mathrm{PGE}_{2}(1 \mu \mathrm{M})$ 
A

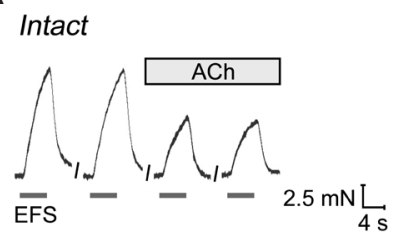

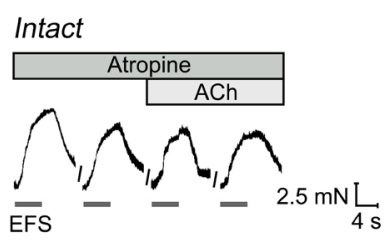

B

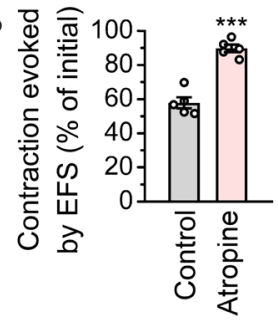

Figure 2 The effect of atropine on acetylcholine (ACh)-induced relaxation in electric field stimulation (EFS)-contracted rat tracheal rings. (A) Representative traces showing the effect of atropine $(2 \mu \mathrm{M})$ on the $20 \mathrm{nM}$ ACh-induced relaxant effect on the contraction evoked by EFS in rat tracheal rings with (B) the corresponding statistical analysis. Data were presented as a percentage of the initial contraction evoked by EFS. Each column and error bar indicated the mean \pm SEM. $n=5$; ${ }^{* * *}, \mathrm{P}<0.001$. The experiment was repeated three times.
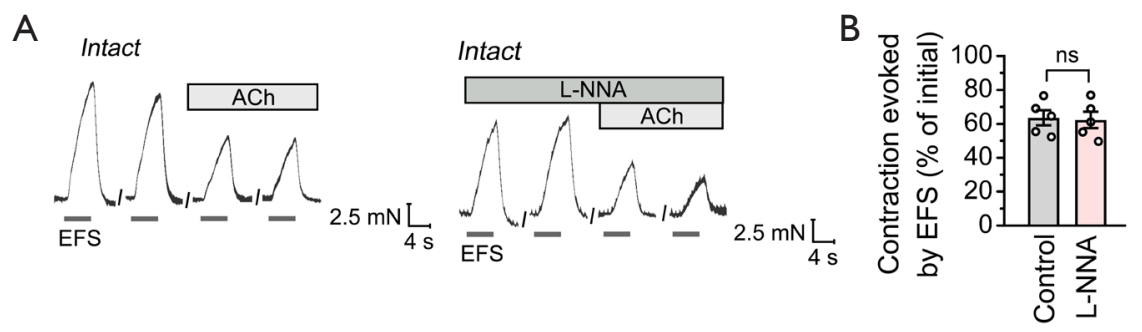

Figure 3 The effect of L-NG-nitro-arginine (L-NNA) on acetylcholine (ACh)-induced relaxation in electric field stimulation (EFS)contracted rat tracheal rings. (A) Representative traces showing the effect of L-NNA $(300 \mu \mathrm{M})$ on the $20 \mathrm{nM}$ ACh-induced relaxant effect on the contraction evoked by EFS in rat tracheal rings with (B) the corresponding statistical analysis. Data were presented as a percentage of the initial contraction evoked by EFS. Each column and error bar indicated the mean \pm SEM. $n=5$; ns: P>0.05. The experiment was repeated at least three times.

significantly restrained the EFS-evoked contraction in both intact and epithelium-denuded tracheal rings (Figure 4C,D), a finding which was similar to that in the intact but not epithelium-denuded tracheal rings treated by $\mathrm{ACh}$ (Figure 1A). These results suggested that epitheliumderived $\mathrm{PGE}_{2}$ might mediate the relaxant effect of $\mathrm{ACh}$ in rat tracheas.

\section{ACb triggered elevation in $\left[\mathrm{Ca}^{2+}\right]_{i}$ and $\mathrm{PGE} \mathrm{E}_{2}$ release in primary cultured rat tracheal epithelial cells}

Intracellular $\mathrm{Ca}^{2+}$ mobilization reportedly mediates COXdependent $\mathrm{PGE}_{2}$ synthesis in epithelial cells $(18,26)$. To further ascertain whether $\mathrm{ACh}$ induced $\mathrm{Ca}^{2+}$ release from intracellular $\mathrm{Ca}^{2+}$ stores via $\mathrm{mAChR}$, which promoted the production of $\mathrm{PGE}_{2}$ in rat tracheal epithelium, we established primary cultures of the epithelial cells from rat trachea (Figure S2). Using a real-time confocal imaging system, we found that ACh $(200 \mu M)$ induced a transient increase in $\left[\mathrm{Ca}^{2+}\right]_{\mathrm{i}}$ in primary cultured rat tracheal epithelial cells (Figure 5A). However, after applying $\mathrm{Tg}(2 \mu \mathrm{M})$ to deplete intracellular $\mathrm{Ca}^{2+}$ stores, the ACh-elicited elevation in $\left[\mathrm{Ca}^{2+}\right]_{\mathrm{i}}$ was abolished (Figure $5 B$ ), suggesting that the ACh-induced $\mathrm{Ca}^{2+}$ response may be attributed to intracellular $\mathrm{Ca}^{2+}$ release. Moreover, atropine $(2 \mu \mathrm{M})$, or the PLC inhibitor U73122 $(10 \mu \mathrm{M})$, abolished the ACh-induced increase in $\left[\mathrm{Ca}^{2+}\right]_{\mathrm{i}}$ (Figure $\left.5 \mathrm{C}, \mathrm{D}\right)$, which confirmed that ACh induced PLC-dependent intracellular $\mathrm{Ca}^{2+}$ mobilization via activation of $\mathrm{mAChR}$ in rat tracheal epithelial cells.

Finally, we detected the $\mathrm{PGE}_{2}$ level secreted by rat tracheal epithelial cells. As illustrated in Figure 6 A, pretreatment with ACh $(200 \mu \mathrm{M})$ induced an increase in the $\mathrm{PGE}_{2}$ content in the supernatants of the primary cultured rat tracheal epithelial cells. However, indomethacin $(10 \mu \mathrm{M})$ potently inhibited ACh-induced $\mathrm{PGE}_{2}$ production. The above results confirmed that ACh facilitated the COXdependent $\mathrm{PGE}_{2}$ synthesis by depleting the internal $\mathrm{Ca}^{2+}$ store via the mAChR-PLC signaling pathway in rat tracheal 
A

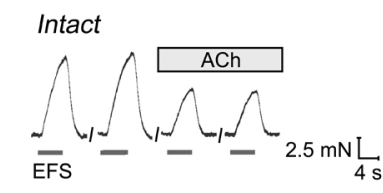

C

Intact

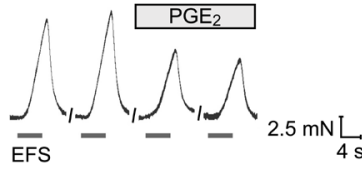

Intact

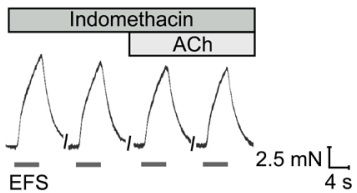

EFS $--1.5 \mathrm{mn}$

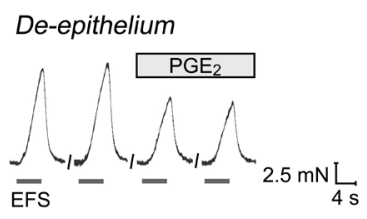

B
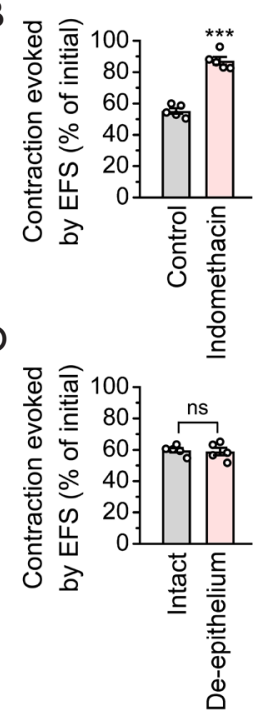

Figure 4 The effect of indomethacin on acetylcholine (ACh)-induced relaxation and the relaxant effect of prostaglandin $\mathrm{E}_{2}\left(\mathrm{PGE}_{2}\right)$ on electric field stimulation (EFS)-contracted rat tracheal rings. (A) Representative traces showing the effect of indomethacin $(10 \mu M)$ on the $20 \mathrm{nM}$ ACh-induced relaxant effect on the contraction evoked by EFS in rat tracheal rings with (B) the corresponding statistical analysis. $\mathrm{n}=5$; ${ }^{* * *}$, $\mathrm{P}<0.001$. (C) Representative traces showing the relaxant effect of $\mathrm{PGE}_{2}(1 \mu \mathrm{M})$ on the contraction evoked by EFS in intact and epitheliumdenuded rat tracheal rings with (D) the corresponding statistical analysis. Data were presented as a percentage of the initial contraction evoked by EFS. Each column and error bar indicated the mean \pm SEM. $n=5$; ns: $P>0.05$. The experiment was repeated at least three times.
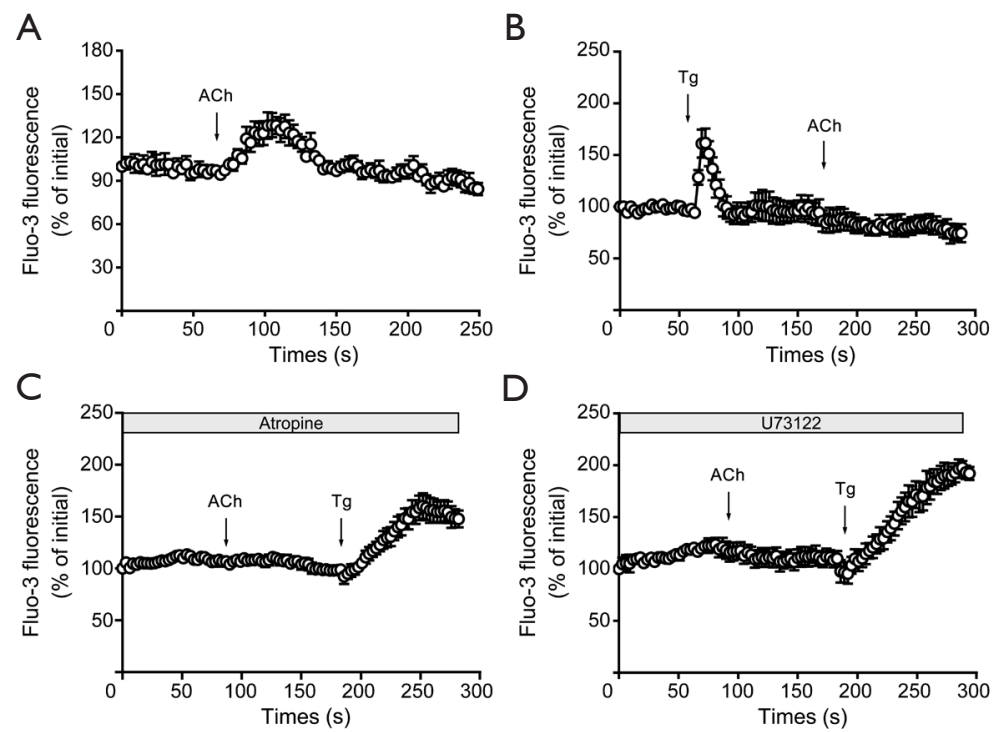

Figure 5 Effect of acetylcholine (ACh) on intracellular $\mathrm{Ca}^{2+}$ concentration $\left\{\left[\mathrm{Ca}^{2+}\right]_{j}\right\}$ in primary cultured rat tracheal epithelial cells. (A) Average time-course trace of $\left[\mathrm{Ca}^{2+}\right]_{i}$ after application of ACh $(200 \mu \mathrm{M})$ in rat tracheal epithelial cells. (B) Average time-course trace of $\left[\mathrm{Ca}^{2+}\right]_{i}$ after applying ACh in $2 \mu \mathrm{M}$ Tg-pretreated rat tracheal epithelial cells. (C) Average time-course trace of $\left[\mathrm{Ca}^{2+}\right]_{\mathrm{i}}$ after applying ACh in $2 \mu \mathrm{M}$ atropinepretreated rat tracheal epithelial cells. Thapsigargin $(\mathrm{Tg}, 2 \mu \mathrm{M})$ was used as a positive control. (D) Average time-course trace of $\left[\mathrm{Ca}^{2+}\right]_{\mathrm{i}}$ after application of ACh in $10 \mu \mathrm{M}$ U73122-pretreated rat tracheal epithelial cells. $\operatorname{Tg}(2 \mu \mathrm{M})$ was used as a positive control. Each symbol and error bar indicated the mean \pm SEM. $n=5$. The experiment was repeated at least three times. 
A

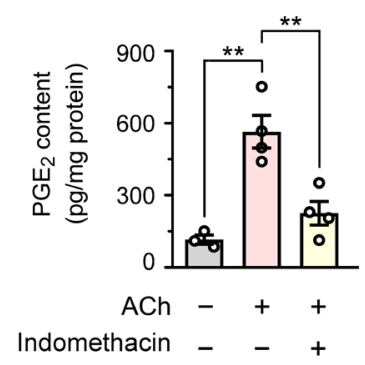

B

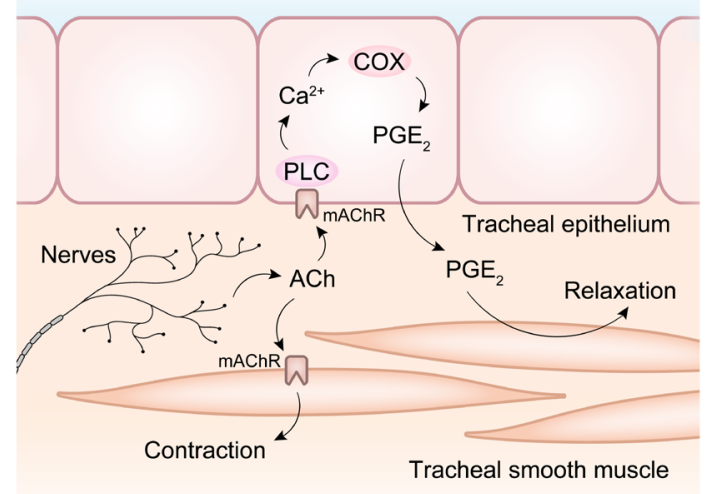

Figure 6 Effect of acetylcholine $(\mathrm{ACh})$ on the release of prostaglandin $\mathrm{E}_{2}\left(\mathrm{PGE}_{2}\right)$ in primary cultured rat tracheal epithelial cells and schematic diagram of epithelium-derived $\mathrm{PGE}_{2}$ in regulating smooth muscle contractility in rat tracheas. (A) Statistical analysis showing the effect of ACh $(200 \mu \mathrm{M})$ on $\mathrm{PGE}_{2}$ content in the presence or absence of indomethacin $(10 \mu \mathrm{M})$ in the rat tracheal epithelial cells. Each column and error bar indicated the mean \pm SEM. $n=3-4 ; * *, P<0.01$. The experiment was repeated at least three times. (B) The neurotransmitter ACh released from parasympathetic nerves has a dual regulatory effect on rat tracheas. On the one hand, ACh directly evokes the contraction of the smooth muscles. On the other hand, ACh mediates epithelium-derived cyclooxygenase (COX)-dependent $\mathrm{PGE}_{2}$ release from epithelial cells via muscarinic $\mathrm{ACh}$ receptors (mAChR)-phospholipase $\mathrm{C}(\mathrm{PLC})-\mathrm{Ca}^{2+}$ signaling, thereby relaxing the smooth muscle cells.

epithelium.

\section{Discussion}

The epithelium-dependent control of smooth muscle tone has been demonstrated in various systems, including airways, gastrointestinal tracts, and reproductive tracts $(5,27,28)$. However, the identity of airway EpiDRFs and their regulatory mechanisms remain to be explored. This study revealed that the neurotransmitter ACh suppressed EFS-evoked contraction of tracheal smooth muscle in an epithelium-dependent manner. Furthermore, the inhibitory effect of ACh was mediated by epithelium-derived $\mathrm{PGE}_{2}$ via the mAChR-PLC-COX signaling pathway, implying an interaction among the smooth muscles, nerves, and epithelia in airways (Figure 6B).

As a prominent endothelium-derived relaxing factor, NO plays a crucial role in regulating vascular tone (29). Previous studies have demonstrated that the endogenous NO synthases, including neuronal NO synthase, endothelial NO synthase, and inductive NO synthase were all detectable in airway epithelium (30). Additionally, exogenous $\mathrm{NO}$ showed a relaxant effect on airway smooth muscle in vitro and in vivo (31), indicating that $\mathrm{NO}$ may be a candidate for EpiDRF in airways. However, our results revealed that after applying the NO synthase inhibitor L-NNA, the inhibitory effect of ACh on EFS-contracted rat tracheal smooth muscle was not altered, ruling out the involvement of endogenous $\mathrm{NO}$ in this process.

It has long been known that $\mathrm{PGE}_{2}$ contributes to epithelium-dependent control of smooth muscle tone in a wide range of organ systems (5). The key enzyme, COX, catalyzes the conversion of arachidonic acid to prostaglandin $\mathrm{H} 2$, an unstable prostaglandin intermediate that is subsequently converted into $\mathrm{PGE}_{2}$ via $\mathrm{PGE}_{2}$ synthase (5). In airways, $\mathrm{PGE}_{2}$ exerts a relaxant effect on the airway smooth muscle cells by acting on the $\mathrm{E}$ prostanoid 2 receptor $(32,33)$. Early evidence showed that the loss of the epithelium or incubation with the non-selective COX inhibitor indomethacin facilitated contractile response to bethanechol in rabbit bronchi (34), which indicated the involvement of $\mathrm{PGE}_{2}$ in epithelium-dependent smooth muscle relaxation. In our study, however, the administration of indomethacin or L-NNA did not significantly alter the basal tone in rat tracheal rings, which indicated that the basal production of prostanoids and NO was low in rat airways as described previously (35). Our study also demonstrated that either pretreatment with indomethacin 
or exogenously applied $\mathrm{PGE}_{2}$ significantly attenuated the inhibitory effect of ACh on EFS-evoked contraction of rat tracheas, which is consistent with previous reports in canine airways (36). These observations suggested that ACh might trigger the release of $\mathrm{PGE}_{2}$, which acted on tracheal smooth muscle and induced relaxation. Indeed, our in vitro study demonstrated that ACh elicited COXdependent $\mathrm{PGE}_{2}$ release from primary cultured rat tracheal epithelial cells, which was in line with other research $(15,16)$. However, it should be noted that indomethacin is a COX inhibitor, and thus the potential involvement of other types of prostaglandins can not be excluded. More investigations are needed to elucidate the critical role of prostaglandins in regulating smooth muscle contraction.

The expression of COX was reportedly associated with $\mathrm{Ca}^{2+}$ signaling in various cell types (18,26,37-39). We thus explored the cellular mechanism underlying ACh-evoked $\mathrm{PGE}_{2}$ production. Using the $\left[\mathrm{Ca}^{2+}\right]_{\mathrm{i}}$ detection technique, we found that ACh induced a transient increase in $\left[\mathrm{Ca}^{2+}\right]_{\mathrm{i}}$, which could be blocked by $\mathrm{Tg}$, atropine, or U73122 in primary cultured rat tracheal epithelial cells. These observations suggested that ACh triggered PLC-dependent $\mathrm{Ca}^{2+}$ release from intracellular $\mathrm{Ca}^{2+}$ stores via activation of mAChR. Parallel to the $\mathrm{Ca}^{2+}$ detection results, atropine also suppressed the epithelium-dependent relaxation induced by ACh in EFS-contracted rat tracheal rings. These observations implied that activation of mAChR evoked $\mathrm{Ca}^{2+}$ release in airway epithelium, which promoted COX-dependent $\mathrm{PGE}_{2}$ release and the subsequent smooth muscle relaxation as described previously (34). Interestingly, after pretreatment with atropine, the contractile response induced by EFS was attenuated. This may be attributed to the inhibitory effect of atropine on the smooth muscle contraction induced by ACh released from vagus nerve terminals.

Airway epithelial cells may respond to signals from the adjacent nerves, immune cells, or pathogens, thereby exerting modulation on airway smooth muscle cells (5). Under physiological conditions, the cellular signaling mediating the release of EpiDRFs such as $\mathrm{PGE}_{2}$ remains unclear. Previous evidence showed that the epithelium-dependent modulating effect on smooth muscle was destroyed in dog lungs when denervation occurred (40), indicating the involvement of neural stimulation in facilitating EpiDRFs release from airway epithelium. Considering the critical roles of the parasympathetic neurotransmitter ACh in regulating airway function, our study may provide a possible explanation for the above observation. Disruption of EpiDRFs production has accounted for smooth muscle disorders, including asthma (27). Given that inhalation of $\mathrm{PGE}_{2}$ alleviated the early and late response to allergens in patients with asthma (41), reconstruction of the mAChR-Ca ${ }^{2+}-\mathrm{COX}-$ $\mathrm{PGE}_{2}$ signaling system in airway epithelium might be a therapeutic strategy for the treatment of respiratory diseases associated with airway hyperresponsiveness.

In conclusion, the neurotransmitter ACh has a dual regulatory effect on rat tracheas by directly contracting the smooth muscles or mediating epithelium-derived $\mathrm{PGE}_{2}$ release via the mAChR-Ca ${ }^{2+}-\mathrm{COX}$ pathway, thereby exerting the relaxant effect on the neighboring smooth muscles. Our study confirms the critical regulatory effect of neurotransmitter-triggered epithelium-derived $\mathrm{PGE}_{2}$ on airway function, providing valuable insights into the crosstalk between epithelial cells and the neighboring cells.

\section{Acknowledgments}

The authors would like to thank Mr. Chong-Feng Lan (School of Life Sciences, Sun Yat-sen University, Guangzhou, China), Mr. Kun-Feng Bai (School of Life Sciences, Sun Yat-sen University, Guangzhou, China) and Dr. Jia-Wen Xu (School of Life Sciences, Sun Yat-sen University, Guangzhou, China) for their excellent technical support.

Funding: This study was supported by the National Natural Science Foundation of China (grant number 81802031, 31771286), the Natural Science Foundation of Guangdong Province (grant number 2016A030313301, 2018A030310074), the Social Science and Technology Research Project of Zhongshan (grant number 2018B1001) and the Medical Research Cooperation Project Between Qingyuan People's hospital and School of Basic Medical Sciences of Guangzhou Medical University (grant number 1014158).

\section{Footnote}

Reporting Checklist: The authors have completed the ARRIVE reporting checklist. Available at http://dx.doi. org/10.21037/atm-20-5500

Data Sharing Statement: Available at http://dx.doi. org/10.21037/atm-20-5500

Conflicts of Interest: All authors have completed the ICMJE uniform disclosure form (available at http://dx.doi. 
org/10.21037/atm-20-5500). The authors have no conflicts of interest to declare.

Ethical Statement: The authors are accountable for all aspects of the work in ensuring that questions related to the accuracy or integrity of any part of the work are appropriately investigated and resolved. Experiments were performed under a project license (No. 0013122401) granted by the institutional ethics board of Sun Yat-sen University, in compliance with Sun Yat-sen University institutional guidelines for the care and use of animals.

Open Access Statement: This is an Open Access article distributed in accordance with the Creative Commons Attribution-NonCommercial-NoDerivs 4.0 International License (CC BY-NC-ND 4.0), which permits the noncommercial replication and distribution of the article with the strict proviso that no changes or edits are made and the original work is properly cited (including links to both the formal publication through the relevant DOI and the license). See: https://creativecommons.org/licenses/by-nc-nd/4.0/.

\section{References}

1. Sanders KM. Regulation of smooth muscle excitation and contraction. Neurogastroenterol Motil 2008;20 Suppl 1:39-53.

2. Kuriyama H, Kitamura K, Itoh T, et al. Physiological features of visceral smooth muscle cells, with special reference to receptors and ion channels. Physiol Rev 1998;78:811-920.

3. Thirstrup S. Control of airway smooth muscle tone. I-electrophysiology and contractile mediators. Respir Med 2000;94:328-36.

4. Canning BJ, Fischer A. Neural regulation of airway smooth muscle tone. Respir Physiol 2001;125:113-27.

5. Ruan YC, Zhou W, Chan HC. Regulation of smooth muscle contraction by the epithelium: role of prostaglandins. Physiology (Bethesda) 2011;26:156-70.

6. Johns RA. Endothelium-derived relaxing factor: basic review and clinical implications. J Cardiothorac Vasc Anesth 1991;5:69-79.

7. Furchgott RF. Endothelium-derived relaxing factor: discovery, early studies, and identification as nitric oxide. Biosci Rep 1999;19:235-51.

8. Vanhoutte PM. Airway epithelium-derived relaxing factor: myth, reality, or naivety? Am J Physiol Cell Physiol 2013;304:C813-20.
9. Wu T, Huang J, Moore PJ, et al. Identification of BPIFA1/ SPLUNC1 as an epithelium-derived smooth muscle relaxing factor. Nat Commun 2017;8:14118.

10. Kim HR, Appel S, Vetterkind S, et al. Smooth muscle signalling pathways in health and disease. J Cell Mol Med 2008;12:2165-80.

11. Kummer W, Lips KS, Pfeil U. The epithelial cholinergic system of the airways. Histochem Cell Biol 2008;130:219-34.

12. Gosens R, Zaagsma J, Grootte Bromhaar M, et al. Acetylcholine: a novel regulator of airway smooth muscle remodelling? Eur J Pharmacol 2004;500:193-201.

13. Racké K, Matthiesen S. The airway cholinergic system: physiology and pharmacology. Pulm Pharmacol Ther 2004;17:181-98.

14. Matera MG, Calzetta L, Passeri D, et al. Epithelium integrity is crucial for the relaxant activity of brain natriuretic peptide in human isolated bronchi. Br J Pharmacol 2011;163:1740-54.

15. Jallat-Daloz I, Cognard JL, Badet JM, et al. Neuralepithelial cell interplay: in vitro evidence that vagal mediators increase PGE2 production by human nasal epithelial cells. Allergy Asthma Proc 2001;22:17-23.

16. Salari H, Chan-Yeung M. Release of 15-hydroxyeicosatetraenoic acid (15-HETE) and prostaglandin E2 (PGE2) by cultured human bronchial epithelial cells. Am J Respir Cell Mol Biol 1989;1:245-50.

17. Zhang YL, Xu JW, Wu XH, et al. Relaxant effect of sodium tanshinone IIA sulphonate on mouse tracheal smooth muscle. Planta Med 2017;83:624-30.

18. Ruan YC, Wang Z, Du JY, et al. Regulation of smooth muscle contractility by the epithelium in rat vas deferens: role of ATP-induced release of PGE2. J Physiol 2008;586:4843-57.

19. Ishii T, Shimo Y. Cooling-induced supersensitivity to acetylcholine in the isolated airway smooth muscle of the rat. Naunyn Schmiedebergs Arch Pharmacol 1985;329:167-75.

20. Ndukwu IM, Solway J, Arbetter K, et al. Immune sensitization augments epithelium-dependent spontaneous tone in guinea pig trachealis. Am J Physiol 1994;266:L485-92.

21. Bramley AM, Samhoun MN, Piper PJ. The role of the epithelium in modulating the responses of guinea-pig trachea induced by bradykinin in vitro. Br J Pharmacol 1990;99:762-6.

22. Luo YL, Guo HM, Zhang YL, et al. Cellular mechanism underlying formaldehyde-stimulated $\mathrm{Cl}$ - secretion in rat 
airway epithelium. PLoS One 2013;8:e54494.

23. Elhusseiny A, Hamel E. Muscarinic--but not nicotinic-acetylcholine receptors mediate a nitric oxide-dependent dilation in brain cortical arterioles: a possible role for the M5 receptor subtype. J Cereb Blood Flow Metab 2000;20:298-305.

24. Griffith TM, Lewis MJ, Newby AC, et al. Endothelium-derived relaxing factor. J Am Coll Cardiol 1988;12:797-806.

25. Furchgott RF, Vanhoutte PM. Endothelium-derived relaxing and contracting factors. FASEB J 1989;3:2007-18.

26. Ruan YC, Guo JH, Liu X, et al. Activation of the epithelial $\mathrm{Na}+$ channel triggers prostaglandin $\mathrm{E} 2$ release and production required for embryo implantation. Nat Med 2012;18:1112-7.

27. Folkerts G, Nijkamp FP. Airway epithelium: more than just a barrier! Trends Pharmacol Sci 1998;19:334-41.

28. Van der Vliet A, Tuinstra TJ, Rademaker B, et al. Role of the epithelium in the control of intestinal motility: implications for intestinal damage after anoxia and reoxygenation. Agents Actions 1992;36:159-67.

29. Farah C, Michel LYM, Balligand JL. Nitric oxide signalling in cardiovascular health and disease. Nat Rev Cardiol 2018;15:292-316.

30. Antosova M, Mokra D, Pepucha L, et al. Physiology of nitric oxide in the respiratory system. Physiol Res 2017;66:S159-72.

31. Hamad AM, Clayton A, Islam B, et al. Guanylyl cyclases, nitric oxide, natriuretic peptides, and airway smooth muscle function. Am J Physiol Lung Cell Mol Physiol 2003;285:L973-83.

32. Tanaka H, Kanako S, Abe S. Prostaglandin E2 receptor selective agonists E-prostanoid 2 and E-prostanoid 4 may have therapeutic effects on ovalbumin-induced bronchoconstriction. Chest 2005;128:3717-23.

33. Tilley SL, Hartney JM, Erikson CJ, et al. Receptors

Cite this article as: Zhao L, Liang YT, Tian DB, Zhang RG, Huang J, Zhu YX, Zhou WL, Zhang YL. Regulation of smooth muscle contractility by the epithelium in rat tracheas: role of prostaglandin $\mathrm{E}_{2}$ induced by the neurotransmitter acetylcholine. Ann Transl Med 2021;9(4):313. doi: 10.21037/atm-20-5500 and pathways mediating the effects of prostaglandin E2 on airway tone. Am J Physiol Lung Cell Mol Physiol 2003;284:L599-606.

34. Butler GB, Adler KB, Evans JN, et al. Modulation of rabbit airway smooth muscle responsiveness by respiratory epithelium. Involvement of an inhibitory metabolite of arachidonic acid. Am Rev Respir Dis 1987;135:1099-104.

35. Bodelsson M, Blomquist S, Caverius K, et al. Substance $\mathrm{P}$ relaxes rat bronchial smooth muscle via epithelial prostanoid synthesis. Respiration 1999;66:355-9.

36. Matsumoto K, Aizawa H, Takata S, et al. Cultured epithelial cells release cyclooxygenase-dependent and cyclooxygenase-independent factors that inhibit cholinergic contraction of canine airway smooth muscles. Respiration 1996;63:205-12.

37. Choi HB, Hong SH, Ryu JK, et al. Differential activation of subtype purinergic receptors modulates $\mathrm{Ca}(2+)$ mobilization and COX-2 in human microglia. Glia 2003;43:95-103.

38. Nakao S, Ogata Y, Modeer T, et al. Bradykinin induces a rapid cyclooxygenase- 2 mRNA expression via $\mathrm{Ca} 2+$ mobilization in human gingival fibroblasts primed with interleukin-1 beta. Cell Calcium 2001;29:446-52 .

39. Shimamoto C, Nakanishi Y, Katsu K, et al. Prostaglandin $\mathrm{E} 2$ release in gastric antral mucosa of guinea-pigs: basal PGE2 release by cyclo-oxygenase 2 and ACh-stimulated PGE2 release by cyclo-oxygenase 1. Exp Physiol 2006;91:1015-24.

40. McLarty AJ, Miller VM, Tazelaar HD, et al. Bronchial contractions in transplanted lungs. Influence of denervation, acute rejection, and the bronchial epithelium. J Thorac Cardiovasc Surg 1993;106:797-804.

41. Pavord ID, Wong CS, Williams J, et al. Effect of inhaled prostaglandin E2 on allergen-induced asthma. Am Rev Respir Dis 1993;148:87-90. 


\section{Appendix 1}

\section{Method}

\section{Immunofluorescence assay}

The primary cultured rat tracheal epithelial cells were grown on the glass coverslips for 3 days. The cells were incubated with a mouse monoclonal antibody against pan cytokeratin (1:100, Wuhan Boster, Wuhan, China) overnight at $4{ }^{\circ} \mathrm{C}$ and incubated with a secondary antibody against mouse $\mathrm{IgG}$ conjugated to fluorescein isothiocyanate (FITC; 1:100, Wuhan Boster, Wuhan, China) for $90 \mathrm{~min}$ at room temperature. Cells were visualized using a fluorescence microscope (Eclipse 50i, Nikon, Tokyo, Japan). The negative control was obtained by omitting the primary antibody.

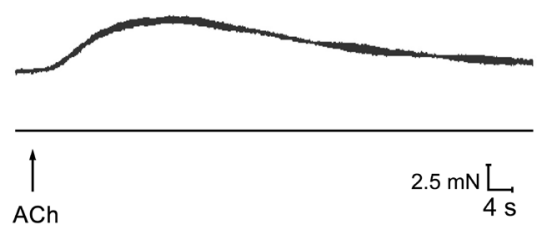

Figure S1 Effect of acetylcholine (ACh) on rat tracheal rings. Representative trace showing the transient contraction response induced by $\mathrm{ACh}(20 \mathrm{nM})$ in rat tracheal ring. The experiment was repeated at least three times.
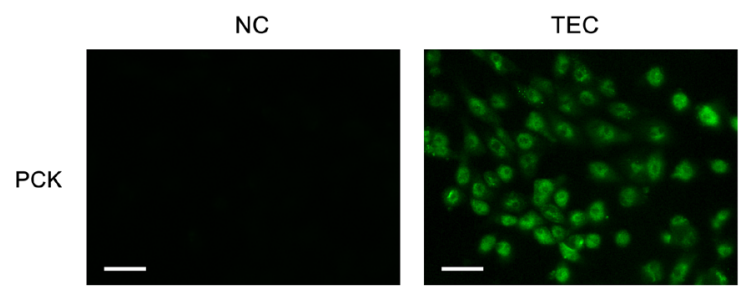

Figure S2 Characterization of the primary cultured rat tracheal epithelial cells. Fluorescence images showing the fluorescein isothiocyanate (FITC) immunoreactivity for PCK, the epithelial cell marker. Scale bars, $25 \mu \mathrm{m}$. NC, negative control; TEC, tracheal epithelial cell; PCK, pan-cytokeratin. 